\title{
The selection of juvenile entrants to mining
}

\author{
J.S. MCLINTOCK \\ The Medical Service of the National Coal Board
}

\begin{abstract}
McLintock, J. S. (1971). Brit. J. industr. Med., 28, 45-51. The selection of juvenile entrants to mining. In $1961 / 62$ a special anthropometric study was made of 1455 young persons entering the coal-mining industry in six mining areas. Five years later a check was made to find those who had left and those who remained.

The average height $(166.27 \mathrm{~cm})$, sitting height $(88.01 \mathrm{~cm})$, and weight $(55.0 \mathrm{~kg})$ of those who continued in mining did not differ significantly from those of the leavers, and corresponded with published data on non-miners of the same age; but there were distinct regional differences in these mean figures.

When comparing the other anthropometric factors of the 'stayers' and 'leavers', the former had significantly lower figures for upper arm girth $(243.5 \mathrm{~mm})$, peak flow rate (410.9 litres), strength $(100.7 \mathrm{~kg})$, genital development, and pubic hair. Nevertheless there were such regional differences that caution is required when extending conclusions in biological studies from one coal field to the industry as a whole.
\end{abstract}

In 1960 a collaborative study by the Medical Service and Industrial Relations Department on the selection and retention of juvenile entrants to mining was proposed. The latter Department had just recently completed an investigation on a sample of young miners and ex-miners in three contrasting areas and had found that some $60 \%$ of entrants who were under the age of 18 when starting pit work left the industry within two years. A proportion could be expected to return to coal mining, but with the records then available this figure could not be established. Nevertheless it was clear that the permanent wastage in this age group was substantial.

A suggestion had been made independently but at the same time within the Medical Service that the physique of juvenile new entrants showed some deterioration at pre-entry medical examinations over the preceding five to 10 years. Although analysis of the records of height and weight of young entrants in one coal field did not support this impression, it was felt that closer attention should be paid to this subject.

As there was no information available on the type of new entrant, either in terms of intelligence, aptitude, or physique, who was most likely to become a successful miner, a joint investigation was planned to determine what selection procedures, if any, might minimize wastage.

\section{Design and methods}

Five areas were selected to cover those parts of the country where the pits were predominantly in urban and in rural settings, whose wastage rates were high and low, and where recruiting was difficult and easy. (Several additional areas, which it was planned to incorporate, had to drop out of the study for a variety of reasons.)

In these areas, young entrants under the age of 18 were given a special medical examination supplementing the normal statutory one. When they started their mining training, they underwent a series of intelligence and aptitude tests supervised by Industrial Relations Department staff. It had originally been hoped to incorporate in these latter tests a further one giving a measure of emotional stability; in the event it did not prove possible in this investigation to develop a test method which was considered to provide valid results.

The physical measurements made by the Medical Service were

(1) standing height

(2) sitting height

(3) weight

(4) body fat (a) over triceps

(b) in the subscapular area 
(5) limb girth around (a) upper arm

(6) peak flow rate

(7) strength

(8) secondary sexual characteristics:

(a) genital development

(b) pubic hair.

Standing and sitting heights in centimetres were measured against an accurate wall scale using a rightangled block.

The balances used to weigh the examinees were checked repeatedly and the subjects were weighed in underpants with bladders emptied.

Harpenden skinfold calipers were used to measure body fat.

Muscle size was assessed by measuring limb girths of the left arm, at the same level as was taken for body fat, and of the left calf at its greatest diameter.

The Wright Peak Flow Meter was used to measure peak flow rates (Wright and McKerrow, 1959).

As these examinations were carried out at various points within each area, a simple piece of apparatus to provide a measure of the strength of both back and leg muscles was devised. This consisted of a base plate to which was attached by a wire a spring balance registering up to $400 \mathrm{lb}$ (181 kg) (Figure). The height of the spring balance from the base plate was adjustable. The height of the handle was adjusted to the level of the tip of the midfinger when the examinee was standing erect with his arms by his sides. The examinee was then asked to grip the handle of the balance, standing with his feet slightly apart, toes in line with the vertical plane in which the balance was held, and knees slightly bent. He was asked to pull steadily and as forcibly as he could, holding it for a second at his maximum pull. The force exerted was recorded as lying within a $10 \mathrm{lb}(4.5 \mathrm{~kg})$ range, e.g., 230 to $240 \mathrm{lb}$ (104 to $109 \mathrm{~kg}$ ) (Cathcart, Hughes, and Chalmers, 1935). The average results have been converted to metric units in Table 5.

Tanner's five-point scales were adopted for both genital development and pubic hair (Tanner, 1962).

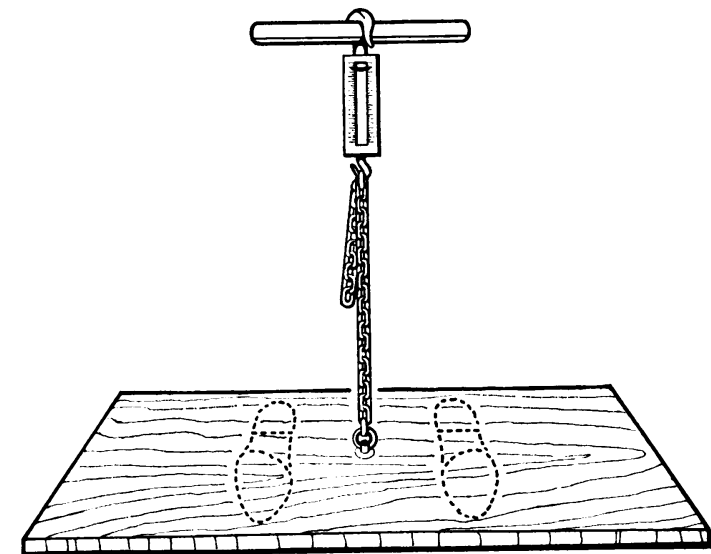

FIGURE Apparatus to measure strength of back and leg muscles.
To minimize inter-observer error all the doctors involved in the investigation attended two sessions in which training in these techniques was given and inter-observer variation was pointed out.

These measurements were made in the latter part of 1961 and the first half of 1962 . In 1966 information on each examinee was obtained from pension and employment records. The questions posed were:

(1) Did this examinee actually start mining work with the Board?

(2) If he did, is he still employed in his original coal field?

(3) If he is still employed there, was his service continuous or interrupted? If broken service, please give dates.

(4) If not so employed, did he transfer to another coal field or leave the industry?

\section{Results}

The numbers examined in the various coal fields and their average ages are shown in Table 1.

TABLE 1

Numbers AND Average Age of Examinees in EACH CoAl Field, $1961 / 2$

\begin{tabular}{l|c|cc}
\hline \multicolumn{1}{c|}{ Coal field } & \multicolumn{3}{|c}{} \\
& $\begin{array}{l}\text { No. of } \\
\text { examinees }\end{array}$ & \multicolumn{2}{|c}{ Average age } \\
& Yr & Mth \\
\hline Northumberland & 123 & 15 & 5 \\
Durham & 345 & 15 & 7 \\
Yorkshire & 226 & 16 & 0 \\
Lancashire & 167 & 15 & 6 \\
South Wales & 406 & 15 & 9 \\
Kent & 188 & 15 & 9 \\
Overall & 1455 & 15 & 7 \\
\end{tabular}

Of the 1455 examinees, close on $10 \%$ did not start their mining apprenticeship, mainly because of physical defects found at examination, while a further $44 \%$ were no longer employed at the time of enquiry in 1966 (Table 2).

In Table 2 it is apparent that, relative to other coal fields, a highly significant proportion of new entrants in Lancashire left mining. No conclusive reason can be provided but during the period of this survey coal mining in Britain was undergoing many changes and contraction was occurring in the old Lancashire and Durham coal fields.

In the remainder of the analysis comparison is made between the 674 examinees who remained in mining and the 642 who started but left. The 139 who did not take up employment are excluded. The tests of statistical significance used throughout are two-sample ' $t$ ' tests. 
TABLE 2

EMPLOYMENT IN THE INDUSTRY IN 1966 OF ThOSE EXAMINED IN 1961/2

\begin{tabular}{|c|c|c|c|c|c|c|c|}
\hline \multirow{2}{*}{\multicolumn{3}{|c|}{ Coal field }} & \multicolumn{2}{|c|}{$\begin{array}{l}\text { Still employed } \\
\text { in mining }\end{array}$} & \multicolumn{2}{|c|}{$\begin{array}{l}\text { Not employed } \\
\text { in mining }\end{array}$} & \multirow{2}{*}{ Total } \\
\hline & & & $\begin{array}{c}\text { Continuous } \\
\text { service }\end{array}$ & $\begin{array}{l}\text { Broken } \\
\text { service }\end{array}$ & $\begin{array}{c}\text { Did not } \\
\text { take up } \\
\text { employment }\end{array}$ & $\begin{array}{l}\text { Left } \\
\text { mining }\end{array}$ & \\
\hline $\begin{array}{l}\text { Northumberland } \\
\text { Durham } \quad . \\
\text { Yorkshire } \quad . \\
\text { Lancashire .. } \\
\text { South Wales . } \\
\text { Kent .. } \quad . .\end{array}$ & $\begin{array}{l}\ldots \\
\ldots \\
\ldots \\
\ldots \\
\ldots \\
\ldots\end{array}$ & $\begin{array}{l}\cdots \\
\cdots \\
\cdots \\
\cdots \\
\cdots \\
\cdots\end{array}$ & $\begin{array}{r}52 \\
190 \\
101 \\
30 \\
185 \\
71\end{array}$ & $\begin{array}{r}1 \\
5 \\
10 \\
5 \\
19 \\
5\end{array}$ & $\begin{array}{l}18 \\
31 \\
18 \\
24 \\
32 \\
16\end{array}$ & $\begin{array}{c}52 \\
119^{2} \\
97 \\
108^{1} \\
170 \\
96\end{array}$ & $\begin{array}{l}123 \\
345 \\
226 \\
167 \\
406 \\
188\end{array}$ \\
\hline \multicolumn{3}{|l|}{ Total } & 629 & 45 & 139 & $642^{1}$ & 1455 \\
\hline \multicolumn{3}{|l|}{ Percentage } & $43 \cdot 2$ & $3 \cdot 1$ & $9 \cdot 6$ & $44 \cdot 1$ & 100 \\
\hline
\end{tabular}

${ }^{1}$ Difference significant at $0.1 \%$ level.

${ }^{2}$ Difference significant at $1 \%$ level.

The mean standing and sitting heights and weights of the examinees in each coal field are shown in Table 3. Only in South Wales was there a significant difference between those who remained in mining and those who left and this is apparent in each parameter, the taller and heavier youths leaving mining.

Because of differences in observers between coal fields, it is undesirable to draw firm conclusions on regional differences but the trends demonstrated in Table 3 are not unexpected.

Table 4 gives the comparable data in respect of body fat and limb girth.

There seems to be a slight tendency for those youths with more body fat to remain in mining, but this was significant only in the Durham coal field. On the other hand, the trend in South Wales was in the opposite direction.

Not surprisingly, in consequence, in most coal fields those examinees who stayed in coal mining had greater limb girths on average than those who left, but once again the opposite was the case in South Wales, the figures being statistically significant.

Table 5 provides the mean values of peak flow rates and strength (as measured in this study). Again such results as are significant arise in the Durham and South Wales coal fields.

A fair correlation $(r=0.5)$ was found between the girth of the upper limb and the result of the strength test but not between body fat over the triceps and strength $(r=0.058)$.

TABLE 3

Mean Standing Heights, Sitting Heights, and Weights of Examinees in Each Coal Field

\begin{tabular}{|c|c|c|c|c|c|c|c|c|}
\hline \multirow{2}{*}{\multicolumn{2}{|c|}{ Coal field }} & & \multicolumn{2}{|c|}{$\begin{array}{l}\text { Mean standing height } \\
(\mathrm{cm})\end{array}$} & \multicolumn{2}{|c|}{$\begin{array}{l}\text { Mean sitting height } \\
(\mathrm{cm})\end{array}$} & \multicolumn{2}{|c|}{ Weight $(k g)$} \\
\hline & & & $\begin{array}{c}\text { Still } \\
\text { employed }\end{array}$ & $\begin{array}{l}\text { Not } \\
\text { employed }\end{array}$ & $\begin{array}{c}\text { Still } \\
\text { employed }\end{array}$ & $\begin{array}{c}\text { Not } \\
\text { employed }\end{array}$ & $\begin{array}{c}\text { Still } \\
\text { employed }\end{array}$ & $\begin{array}{c}\text { Not } \\
\text { employed }\end{array}$ \\
\hline $\begin{array}{l}\text { Northumberlar } \\
\text { Durham. . } \\
\text { Yorkshire } \\
\text { Lancashire } \\
\text { South Wales } \\
\text { Kent . . }\end{array}$ & $\begin{array}{l}\text { Ind } \\
\ldots \\
\ldots \\
\ldots \\
\ldots \\
\ldots\end{array}$ & $\begin{array}{l}\ldots \\
\ldots \\
\cdots \\
\ldots \\
\cdots \\
\ldots\end{array}$ & $\begin{array}{l}167 \cdot 74 \\
165 \cdot 40 \\
168 \cdot 20 \\
164 \cdot 94 \\
164 \cdot 32^{2} \\
170 \cdot 53\end{array}$ & $\begin{array}{l}165 \cdot 75 \\
164 \cdot 84 \\
167 \cdot 23 \\
166 \cdot 78 \\
166 \cdot 44^{2} \\
168 \cdot 99\end{array}$ & $\begin{array}{l}88 \cdot 28 \\
87 \cdot 40 \\
89 \cdot 07 \\
86 \cdot 51 \\
87 \cdot 61^{3} \\
89 \cdot 57\end{array}$ & $\begin{array}{l}86 \cdot 87 \\
87 \cdot 27 \\
88 \cdot 47 \\
87 \cdot 45 \\
88 \cdot 84^{3} \\
88 \cdot 85\end{array}$ & $\begin{array}{l}57 \cdot 3 \\
54 \cdot 3 \\
56 \cdot 5 \\
54 \cdot 0 \\
53 \cdot 1 \\
58 \cdot 3\end{array}$ & $\begin{array}{l}56 \cdot 2 \\
53 \cdot 5 \\
54 \cdot 7 \\
55 \cdot 6 \\
56 \cdot 1^{1} \\
57 \cdot 1\end{array}$ \\
\hline \multicolumn{3}{|l|}{ All coal fields } & $166 \cdot 27$ & 166.64 & 88.01 & $88 \cdot 10$ & $55 \cdot 0$ & $55 \cdot 5$ \\
\hline
\end{tabular}

${ }^{1}$ Difference significant at $1 \%$ level. ${ }^{2}$ Difference significant at $2 \%$ level. ${ }^{3}$ Difference significant at $5 \%$ level. 
TABLE 4

Mean Body Fat and Limb Girths of Examineees in Each Coal Field

\begin{tabular}{|c|c|c|c|c|c|c|c|c|c|c|}
\hline \multirow{3}{*}{ Coal field } & & & \multicolumn{4}{|c|}{ Mean body fat $(\mathrm{mm})$} & \multicolumn{4}{|c|}{ Mean limb girth $(\mathrm{mm})$} \\
\hline & & & \multicolumn{2}{|c|}{ Triceps } & \multicolumn{2}{|c|}{ Subscapular } & \multicolumn{2}{|c|}{ Upper limb } & \multicolumn{2}{|c|}{ Lower limb } \\
\hline & & & $\begin{array}{c}\text { Still } \\
\text { employed }\end{array}$ & $\begin{array}{c}\text { Not } \\
\text { employed }\end{array}$ & $\begin{array}{c}\text { Still } \\
\text { employed }\end{array}$ & $\begin{array}{c}\text { Not } \\
\text { employed }\end{array}$ & $\begin{array}{c}\text { Still } \\
\text { employed }\end{array}$ & $\begin{array}{c}\text { Not } \\
\text { employed }\end{array}$ & $\begin{array}{c}\text { Still } \\
\text { employed }\end{array}$ & $\begin{array}{c}\text { Not } \\
\text { employed }\end{array}$ \\
\hline $\begin{array}{l}\text { Northumberland } \\
\text { Durham } \quad . . \\
\text { Yorkshire .. } \\
\text { Lancashire .. } \\
\text { South Wales } \\
\text { Kent . . . }\end{array}$ & $\begin{array}{l}\cdots \\
\cdots \\
\cdots \\
\cdots \\
\cdots\end{array}$ & $\begin{array}{l}\ldots \\
\ldots \\
\cdots \\
\cdots \\
\cdots\end{array}$ & $\begin{array}{l}7 \cdot 12 \\
7 \cdot 76^{1} \\
8 \cdot 02 \\
8 \cdot 03 \\
8 \cdot 27 \\
9 \cdot 41\end{array}$ & $\begin{array}{l}6 \cdot 74 \\
6 \cdot 52^{1} \\
7 \cdot 41 \\
7 \cdot 85 \\
8 \cdot 57 \\
8 \cdot 83\end{array}$ & $\begin{array}{l}7 \cdot 82 \\
7 \cdot 21^{3} \\
7 \cdot 03 \\
7 \cdot 48 \\
6 \cdot 84 \\
8 \cdot 35\end{array}$ & $\begin{array}{l}7 \cdot 47 \\
6 \cdot 60^{3} \\
6 \cdot 61 \\
8 \cdot 05 \\
7 \cdot 04 \\
7 \cdot 99\end{array}$ & $\begin{array}{l}243 \cdot 8 \\
241 \cdot 1 \\
245 \cdot 6 \\
250 \cdot 8 \\
241 \cdot 5^{2} \\
248 \cdot 4\end{array}$ & $\begin{array}{l}242 \cdot 7 \\
239 \cdot 8 \\
241 \cdot 0 \\
265 \cdot 6 \\
251 \cdot 5^{2} \\
246 \cdot 3\end{array}$ & $\begin{array}{l}335 \cdot 2 \\
334 \cdot 7 \\
335 \cdot 0 \\
326 \cdot 3 \\
328 \cdot 5^{3} \\
343 \cdot 5\end{array}$ & $\begin{array}{l}334 \cdot 2 \\
333 \cdot 2 \\
332 \cdot 1 \\
325 \cdot 3 \\
335 \cdot 2^{3} \\
342 \cdot 1\end{array}$ \\
\hline All coal fields & .. & $\ldots$ & $8 \cdot 11$ & $7 \cdot 78$ & $7 \cdot 26$ & $7 \cdot 24$ & $243 \cdot 5^{2}$ & $248 \cdot 6^{2}$ & $333 \cdot 5$ & 333.6 \\
\hline
\end{tabular}

${ }^{1}$ Difference significant at $0.1 \%$ level.

${ }^{2}$ Difference significant at $1 \%$ level.

${ }^{3}$ Difference significant at $5 \%$ level.

It is possible that many of these findings could be explained by selective departure of older or younger examinees. Table 6 shows for each coal field the average ages of those who remained in mining and those who left. In each area it was the younger who remained and in some this finding was statistically significant.

The average scores of secondary sexual characteristics are given in Table 7.

Of the various measurements recorded these are the most subjective in assessment, and therefore some intra-observer error is to be expected.

No clear-cut pattern is apparent as to whether the more mature youths stay in or leave mining except in South Wales and Lancashire, where it was found that the more mature left the industry.

Information on the duration of employment of those youths who started their mining apprenticeship could be obtained in only 346 cases (see Table 8 ) but from this limited information it would appear that young men who leave the industry are likely to do so within their first three years of employment. This is not surprising as it is after approximately three years' training that youths begin to be employed on the coal face where wages are substantially greater than in other mining work.

\section{Discussion}

Hammond (1953) reported various anthropometric

TABLE 5

Mean Peak Flow Rates and Mean Strength of Examinees in Each Coal Field

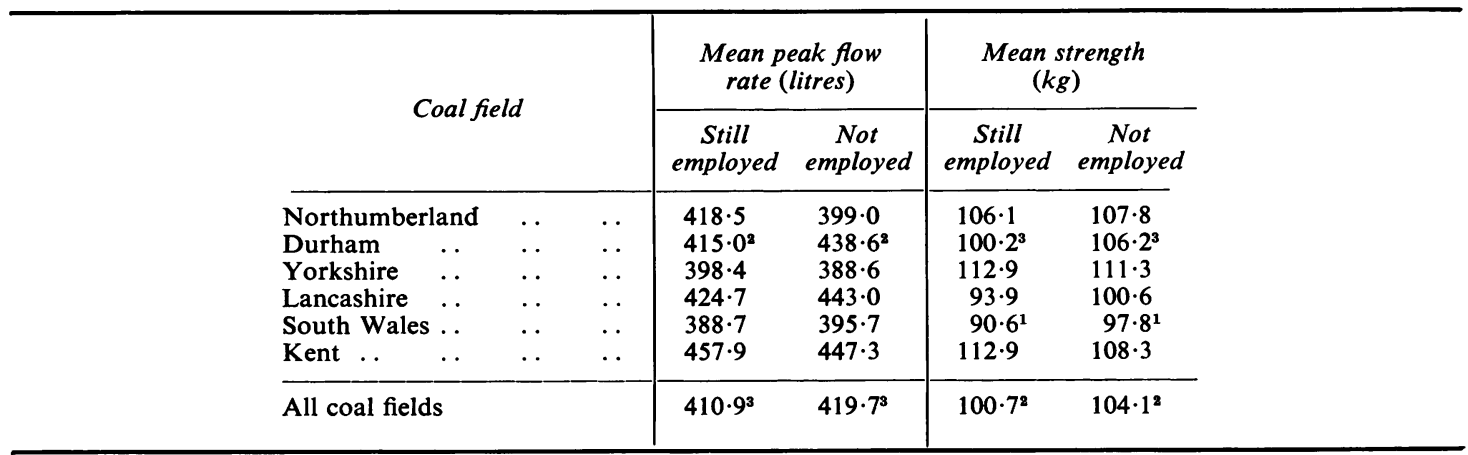

${ }^{1}$ Difference significant at $0.1 \%$ level.

'Difference significant at $1 \%$ level.

${ }^{3}$ Difference significant at $5 \%$ level. 
TABLE 6

Average Ages on Recruitment of Examinees in EACH COAL Field

\begin{tabular}{l|cc|cc}
\hline \multirow{2}{*}{ Coal field } & \multicolumn{2}{|c|}{ Still employed } & \multicolumn{2}{c}{ Not employed } \\
\cline { 2 - 5 } & Years & Months & Years & Months \\
\hline Northumberland & 15 & 8 & 15 & 10 \\
Durham & 15 & $4^{2}$ & 15 & $7^{2}$ \\
Yorkshire & 15 & 7 & 15 & 8 \\
Lancashire & 15 & 11 & 16 & 0 \\
South Wales & 15 & $5^{1}$ & 15 & $8^{1}$ \\
Kent & 15 & $6^{3}$ & 15 & $11^{3}$ \\
\hline All coal fields & 15 & $5^{1}$ & 15 & $9^{1}$ \\
\hline
\end{tabular}

${ }^{1}$ Difference significant at $0 \cdot 1 \%$ level

${ }^{2}$ Difference significant at $1 \%$ level

${ }^{3}$ Difference significant at $2 \%$ level

TABLE 7

Average Score of Secondary Sexual Characteristics of Examinees in EACH COAL Field

\begin{tabular}{l|cc|cc}
\hline \multirow{2}{*}{ Coal field } & \multicolumn{2}{|c|}{ Genital development } & \multicolumn{2}{|c}{ Pubic hair } \\
\cline { 2 - 5 } & $\begin{array}{c}\text { Still } \\
\text { employed employed }\end{array}$ & $\begin{array}{c}\text { Not } \\
\text { Still }\end{array}$ & $\begin{array}{c}\text { Not } \\
\text { employed employed }\end{array}$ \\
\cline { 2 - 5 } Northumberland & $4 \cdot 6$ & $4 \cdot 4$ & $4 \cdot 4$ & $4 \cdot 5$ \\
Durham & $3 \cdot 7$ & $3 \cdot 8$ & $3 \cdot 7$ & $3 \cdot 8$ \\
Yorkshire & $4 \cdot 5$ & $4 \cdot 4$ & $4 \cdot 3$ & $4 \cdot 2$ \\
Lancashire & $4 \cdot 0$ & $4 \cdot 2$ & $3 \cdot 7^{3}$ & $4 \cdot 2^{3}$ \\
South Wales & $4 \cdot 3^{2}$ & $4 \cdot 6^{2}$ & $4 \cdot 2^{3}$ & $4 \cdot 4^{3}$ \\
Kent & $3 \cdot 7$ & $3 \cdot 7$ & $3 \cdot 6$ & $3 \cdot 7$ \\
\hline All coal fields & $4 \cdot 1^{3}$ & $4 \cdot 2^{3}$ & $4 \cdot 0^{1}$ & $4 \cdot 2^{1}$ \\
\hline
\end{tabular}

${ }^{1}$ Difference significant at $1 \%$ level

${ }^{2}$ Difference significant at $2 \%$ level

${ }^{3}$ Difference significant at $5 \%$ level

TABLE 8

Duration of Initial Period of Employment in 346 EXAMINEES

\begin{tabular}{c|c}
\hline Period $($ mth $)$ & No. leaving \\
\hline $0-5$ & 51 \\
$6-11$ & 53 \\
$12-17$ & 40 \\
$18-23$ & 36 \\
$24-29$ & 51 \\
$30-35$ & 61 \\
$36-41$ & 40 \\
$42-47$ & 13 \\
Over 47 & 1 \\
\hline
\end{tabular}

measurements of school children; these measurements were made between 1945 and 1952. Table 9 is extracted from his data to permit such comparison as is possible with the results reported here.

TABLE 9

Heights AND Weights of Children Aged 15 AND 16

\begin{tabular}{l|cc|c}
\hline & \multicolumn{2}{|c|}{ Age 15 years } & Age 16 years \\
\cline { 2 - 4 } & $\begin{array}{c}\text { At independent } \\
\text { schools }\end{array}$ & $\begin{array}{c}\text { At council } \\
\text { schools in } \\
\text { poor area }\end{array}$ & $\begin{array}{c}\text { At independent } \\
\text { schools }\end{array}$ \\
\hline $\begin{array}{l}\text { Standing } \\
\text { height (cm) }\end{array}$ & $167 \cdot 2$ & $158 \cdot 5$ & 173.3 \\
$\begin{array}{l}\text { Sitting } \\
\text { height (cm) } \\
\text { Weight }\end{array}$ & 88.2 & 83.4 & $91 \cdot 1$ \\
\hline
\end{tabular}

${ }^{1}$ No data available for 16 -year-olds at council schools.

Tanner and Whitehouse (1959), in growth and development records, calculated the average height and weight of $15 \frac{1}{2}$-year-old boys as $166.5 \mathrm{~cm}$ and $54.25 \mathrm{~kg}$ respectively. In more recent work relating to children in 1965 (Tanner, Whitehouse, and Takaishi, 1966) the corresponding figures are given as $170 \mathrm{~cm}$ and $57 \cdot 4 \mathrm{~kg}$.

Ward (1965) gave the average height and weight of a group of 608 young entrants to coal mining between 1952 and 1962 as $165 \cdot 28 \mathrm{~cm}$ and $54 \cdot 81 \mathrm{~kg}$. This group was aged 15 and the average age was $15 \frac{1}{2}$; the coal field concerned covered Leicestershire and South Derbyshire.

These three authors are in close agreement but are reporting averages. It is known that regional differences in stature are present. Clements and Pickett (1957) examined the 1941 records of National Service Medical Boards for men aged between 17 and 50. A part of their findings is summarized below in Table 10.

TABLE 10

Average Heights and Weights in Various Regions of National Service Medical Board EXAMINEES

\begin{tabular}{l|c|c}
\hline \multicolumn{1}{c|}{ Region } & Height $(\mathrm{cm})$ & Weight $(\mathrm{kg})$ \\
\hline Northumberland \& Durham & $168 \cdot 94$ & $60 \cdot 9$ \\
South Wales & $168 \cdot 99$ & $60 \cdot 4$ \\
Lancashire & $169 \cdot 49$ & $60 \cdot 3$ \\
West Riding of Yorkshire & $170 \cdot 28$ & $61 \cdot 2$ \\
South-east England & $171 \cdot 60$ & $62 \cdot 7$ \\
(including Kent) & & \\
\hline
\end{tabular}


The similarity in trend between the findings reported in this study and those of Hammond, Tanner, and Ward are obvious; while the regional variations shown by Clements and Pickett are still found to follow very much the same pattern.

In respect of limb girth and body fat, Hammond $(1953 ; 1955)$ has also provided comparable information (Table 11).

TABLE 11

ARM GirTh

\begin{tabular}{c|cc|c}
\hline & \multicolumn{2}{|c|}{ Age 15 years } & Age 16 years \\
\cline { 2 - 3 } & $\begin{array}{c}\text { At inde- } \\
\text { pendent } \\
\text { schools }\end{array}$ & $\begin{array}{l}\text { At council } \\
\text { schools in } \\
\text { poor area }\end{array}$ & $\begin{array}{c}\text { At inde- } \\
\text { pendent } \\
\text { schools }\end{array}$ \\
\hline Arm girth (mm) & 227 & 216 & 237 \\
\hline $\begin{array}{c}\text { Body fat (mm) } \\
\text { Over triceps } \\
\text { In sub-scapular } \\
\text { area }\end{array}$ & Age 15 years & Age 16 years \\
\hline
\end{tabular}

It is a little surprising, in view of the close agreement in the previous measurements, that Hammond's figures for arm girth and body fat should be so distinctly lower than those found in this investigation in mining recruits, many of whom have just left school. No explanation can be offered.

There is little information available on peak flow rates in the 15-year-old age group, but Nairn, Bennet, Andrew, and MacArthur (1961) gave an equation based on height for calculating peak flow rates. For boys this is $\mathbf{1 4 . 2 0 3} \times$ height in inches $476 \cdot 24$, with a standard deviation of $13.4 \%$; and for heights of 1.6 and 1.7 metres (the range found in their investigation) the calculated flow rates are 420 and 470 litres respectively. The peak flow rates found in this study are not out of line with Nairn's equation, although a little lower.

The apparatus used to measure the strength of back and leg muscles was a modification of that used by Cathcart et al. (1935) and therefore the results are unlikely to be directly comparable. However, in 197 subjects aged 15 , with an average age of $15 \frac{1}{2}$ years, Cathcart recorded an average 'pull' of $124 \mathrm{~kg}$ in this type of test, a figure of the same order as that found in this study.

From such comparisons with other recorded data it would seem that the physique of juvenile new entrants to coal mining in 1961/62 was a reasonable average for this age group. However, there was evidence to suggest that in some coal fields the fitter youths left coal mining while elsewhere the reverse applied. Table 12 summarizes the findings in this investigation.

As these examinations were carried out, in the great majority of cases, even before the youths started work, the doctors concerned could have had no knowledge of those who were likely to remain in or to leave coal mining. In this respect the comparison of the physique of the two groups of 'stayers' and 'leavers' must be unbiased. In Yorkshire and Kent it was clearly the taller, heavier, and fitter young men who stayed in the pits. In South Wales and Lancashire the reverse obtained. Northumberland and Durham occupied an intermediate position.

It could be argued that the loss of the taller, fitter youths in South Wales was simply a reflection of the departure of the somewhat older recruits, but this could scarcely be said of Lancashire where there was only one month's difference in age between 'stayers' and 'leavers'. Yorkshire, too, showed a similar one month's difference, and Kent had a substantial age gap, again with the older leaving.

TABLE 12

ANTHRopometricData Summary: Examinees Still Employed Compared with Those NoLonger in Mining

\begin{tabular}{|c|c|c|c|c|c|c|c|c|c|c|c|c|}
\hline \multirow{3}{*}{ Coal field } & \multirow{3}{*}{$\begin{array}{c}\text { Standing } \\
\text { height }\end{array}$} & \multirow{3}{*}{$\begin{array}{l}\text { Sitting } \\
\text { height }\end{array}$} & \multirow{3}{*}{ Weight } & \multirow{2}{*}{\multicolumn{2}{|c|}{ Body fat }} & \multirow{2}{*}{\multicolumn{2}{|c|}{ Limb girth }} & \multirow{3}{*}{$\begin{array}{l}\text { Peak } \\
\text { flow } \\
\text { rate }\end{array}$} & \multirow{3}{*}{ Strength } & \multicolumn{2}{|c|}{$\begin{array}{l}\text { Secondary sexual } \\
\text { characteristics }\end{array}$} & \multirow{3}{*}{ Age } \\
\hline & & & & & & & & & & \multirow{2}{*}{$\begin{array}{c}\text { Genital } \\
\text { develop- } \\
\text { ment }\end{array}$} & \multirow{2}{*}{$\begin{array}{l}\text { Pubic } \\
\text { hair }\end{array}$} & \\
\hline & & & & $\begin{array}{c}\text { Over } \\
\text { triceps }\end{array}$ & $\begin{array}{l}\text { Over sub- } \\
\text { scapular }\end{array}$ & Upper & Lower & & & & & \\
\hline $\begin{array}{l}\text { Northumberland } \\
\text { Durham } \\
\text { Yorkshire } \\
\text { Lancashire } \\
\text { South Wales } \\
\text { Kent }\end{array}$ & $\begin{array}{l}\text { Taller } \\
\text { Taller } \\
\text { Taller } \\
\text { Smaller } \\
\text { Smaller } \\
\text { Taller }\end{array}$ & $\begin{array}{l}\text { Taller } \\
\text { Taller } \\
\text { Taller } \\
\text { Smaller } \\
\text { Smaller } \\
\text { Taller }\end{array}$ & $\begin{array}{l}\text { Heavier } \\
\text { Heavier } \\
\text { Heavier } \\
\text { Lighter } \\
\text { Lighter } \\
\text { Heavier }\end{array}$ & $\begin{array}{l}\text { More } \\
\text { More } \\
\text { More } \\
\text { More } \\
\text { Less } \\
\text { More }\end{array}$ & $\begin{array}{l}\text { More } \\
\text { Mored } \\
\text { More } \\
\text { Less } \\
\text { Less } \\
\text { More }\end{array}$ & $\begin{array}{l}\text { Larger } \\
\text { Larger } \\
\text { Larger } \\
\text { Smaller } \\
\text { Smaller² } \\
\text { Larger }\end{array}$ & $\begin{array}{l}\text { Larger } \\
\text { Larger } \\
\text { Larger } \\
\text { Larger } \\
\text { Smaller } \\
\text { Larger }\end{array}$ & $\begin{array}{l}\text { Higher } \\
\text { Lower' } \\
\text { Higher } \\
\text { Lower } \\
\text { Lower } \\
\text { Higher }\end{array}$ & $\begin{array}{l}\text { Less } \\
\text { Less` } \\
\text { More } \\
\text { Less } \\
\text { Less } \\
\text { More }\end{array}$ & $\begin{array}{l}\text { Greater } \\
\text { Less } \\
\text { Greater } \\
\text { Less } \\
\text { Less } \\
\text { Same }\end{array}$ & $\begin{array}{l}\text { Less } \\
\text { Less } \\
\text { More } \\
\text { Less` } \\
\text { Less` } \\
\text { Less }\end{array}$ & $\begin{array}{l}\text { Younger } \\
\text { Younger } \\
\text { Younger } \\
\text { Younger } \\
\text { Younger } \\
\text { Younger }^{2}\end{array}$ \\
\hline
\end{tabular}

${ }^{1}$ Difference significant at $0.1 \%$ level.

Difference significant at $1 \%$ level.

'Difference significant at $2 \%$ level.

Difference significant at $5 \%$ level. 
The evidence from this investigation suggests that in South Wales and Lancashire those juvenile new entrants to mining, who remain in the industry for five years or more, are of poorer physique than average, while in Kent and Yorkshire the opposite obtains. As a corollary, this study emphasizes the dangers of drawing conclusions related to the whole industry from biological studies in one coal field.

Finally, as expected, anthropometric measurements did not provide a sufficiently accurate guide to be used as a selection procedure to minimize wastage.

\section{Conclusions}

(1) In $1961 / 62$ the physique of the average new entrant to coal mining was much the same as that for young persons in general of the same age.

(2) There were appreciable regional differences in physique and in some coal fields the fitter remained in mining whereas in others they left.

(3) Such regional differences emphasize the need for caution in extending conclusions in biological studies from one coal field to the industry as a whole.

(4) Anthropometric measurements, as carried out in this study, do not serve a useful purpose as a selection procedure to minimize wastage.

I am grateful to Professor J. M. Tanner and Mr. R. H. Whitehouse of the Institute of Child Health for their advice and guidance on the anthropometric measures used. I also acknowledge with appreciation the help of Mr. (now Professor) F. D. K. Liddell and his staff in the statistical analysis of the data. The field work was carried out by Drs. N. C. Haswell, A. A. Lawson,
J. Lockie, W. B. Roantree, R. W. Shepherd, and D. M. Williamson, without whose active co-operation this report could not have been written.

\section{References}

Cathcart, E. P., Hughes, D. E. R., and Chalmers, J. G., (1935). The Physique of Man in Industry. Rep. industr. Hlth Res. Bd (Lond.) No. 71. H.M.S.O., London.

Clements, E. M. B., and Pickett, K. G. (1957). Stature and weight of men from England and Wales in 1941. Brit. J. prev. soc. Med., 11, 51-60.

Hammond, W. H. (1953). Physique and development of boys and girls from different types of school. Brit. $J$. prev. soc. Med., 7, 231-239.

(1955). Measurement and interpretation of subcutaneous fat, with norms for children and young adult males. Brit. J. prev. soc. Med., 9, 201-211.

Nairn, Jean R., Bennet, A. J., Andrew, J. D., and MacArthur, P. (1961). A study of respiratory function in normal school children. The peak flow rate. Arch. Dis. Childh., 36, 253-258.

Tanner, J. M. (1962). Growth at Adolescence, 2nd ed. Blackwell, Oxford.

- and Whitehouse, R. H. (1959). Standards for height and weight of British children from birth to maturity. Lancet, 2, 1086-1088.

-, , and Takaishi, M. (1966). Standards from birth to maturity for height, weight, height velocity, and weight velocity: British children, 1965. Arch. Dis. Childh., 41, 454-471; 613-635.

Ward, Joan S. (1965). Weights, heights and chest circumferences of English East Midland coal miners in 1952-62. Hum. Biol., 37, 299-311.

Wright, B. M., and McKerrow, C. B. (1959). Maximum forced expiratory flow rate as a measure of ventilatory capacity, with a description of a new portable instrument for measuring it. Brit. med. J., 2, 1041-1047.

Received for publication April 23, 1970. 